\title{
Stock Price Synchronicity with Analyst Coverage and Disclosure of Information in Iran Capital Market
}

\author{
Sirvan Amini \\ PhD student, Kish International Campus, University of Tehran \\ Ezzatolah Abbasian \\ Associate Professor in Economics, Department of economics, \\ $\mathrm{Bu}$ Ali Sina University, Hamedan, Iran \\ Reza Tehrani \\ Professor in financial management, faculty of management, \\ University of Tehran, Tehran, Iran
}

\begin{abstract}
In this study, Stock Price Synchronicity with Analyst Coverage and Disclosure of Information during the years 1390 to 1396 have been studied and compared. The statistical population of the study consists of companies listed on the Tehran Stock Exchange and Iran Fara Bourse(IFB). Research hypotheses have been tested through a multivariate regression equation. The main research hypothesis regarding the relationship between stock price synchronization and analyst coverage and disclosure of significant positive relationship has been confirmed. Other findings suggest a significant positive relationship between stock price synchronization and disclosure and irrelevency between analyst coverage and stock price synchronization. An increase in the number of analysts on the one hand and a slight increase in the number of announcements published by the companies surveyed in the Codal system on the other hand has shown a positive relationship between these two variables and the price variable. In other words, as the synchronicity increases, the greater the number of announcements and the greater the number of analysts, the more synchronicity the stock price will be.
\end{abstract}

Keywords: Price Synchronicity, Analyst Coverage, Disclosure of Information.

DOI: $10.7176 /$ RJFA/12-3-01

Publication date: February $28^{\text {th }} 2021$

\section{Introduction}

Universally, the significance of the vibrancy, healthiness, and transparency of the banking sector to the growth and development of economies cannot be overemphasized in that it ensures adequate mobilization and intermediation of fund through which economies thrive. It must be noted that the level of functioning of the banking sector depends on the patronage of the customers towards its services coupled with the assurance of quality services (Agbaeze \& Ogosi, 2018). This informs that the loss of confidence by the populace in the activities of the firms in the banking sector, particularly Deposit Money Banks, could engender panic among the minor (employees) and major (shareholders) stakeholders, move the volatility of the economy to the extreme and, in the same vein, breed economic and financial woes (Adegbemi, Donald \& Ismail, 2013).

On this note, Mohammed (2012) observed that the environment of Deposit Money Banks (DMBs) demands transparency of operational activities given that the costs of institutional failure (considering the multiplier effect of financial institutional failure on the real sector of the economy) are excessively costly to a country like Nigeria. The consequences of corporate failure will not only affect the shareholders but also, suppliers, employees, customers, and the entire nation. Expanding this, literature affirmed that the absence of confidence in the operational activities of the banking sector is toxic to the performance level mostly measures in terms of Return on Assets (ROA), Return on Equity (ROE), Net Profit Margin (NPM) and Profit after Tax (PAT) (Adigwe, Nwanna \& John, 2016; Pitambar, 2017).

Corporate governance seems to be the engine room through which operational activities of organizations are performed. According to World Bank cited in Pitambar (2017), it is the system by which an entity is regulated, operated, controlled and monitored for promoting the transparency, fairness, and accountability of firms. Attesting to this, Okafor (2011) posits that corporate governance connotes the procedures involved in the discharge of the mandate of governance in corporate entities. This underpins that corporate governance deals with policies, procedures, structures, policies being applied by business firms to achieve target objectives. It is the structure through which the firm's objectives are set and attained.

Bank corporate governance involves internal and external corporate governance mechanisms. Internal corporate governance mechanisms include board composition, gender diversity, board size, the Chief Executive officer (CEO) duality, while external corporate governance mechanisms include but not limited to the audit committee and the government regulations (Zabri, Ahmad \& Wah 2016; Salma \& Cesario, 2016). In this study, 
some of the most influential internal and external corporate mechanisms such as board composition, gender diversity, board size, the CEO duality and board audit committee are used. The choice of all these variables is based on the affirmation of scholars that they are the most influential indicators of corporate governance affecting the performance level of banks (Salma \& Cesario, 2016; Mohammed \& Fahmida, 2017).

Notably, the banking sector in Nigerian has grown remarkably over the years in terms of the breadth and depth of the operational activities, ownership structure, number of institutions and consolidation policies. Consequently, the industry has been shaped by many factors and events not limited to regulatory guidelines, deregulation of the financial sector, globalization of operations, advancements in technology and impact of the global economic downturn. All these advances appear to affect the operational activities of banks occasioned by many failures in the industry.

The recent merger of banks in Nigeria engendered by different consolidations policies and antecedents of failed banks between the year 2006 and till date concern on the need to improve corporate governance of banks to stimulate uprightness and financial soundness. This is expected to boost public confidence and ensure efficient and effective functioning of the banking system. According to Mugisha, Jaya, Joseph and Mbabazi (2015), banking supervision can only function well if sound corporate governance is in place. Consequently, banking supervisors have a strong interest in ensuring that there is effective corporate governance at every banking organization.

Universally, a lot of studies have been carried out on the significance of corporate governance on the performance of banks in developed, developing and Nigeria with different variables. For instance, Mugisha, Jaya, Joseph and Mbabazi (2015) investigated the effect of corporate governance on financial performance of commercial banks in Rwanda with predictor variables of CEO duality, board composition, institutional ownership, and ROA and ROE as measures of performance. Salma and Cesario (2016) investigated the impact of corporate governance on European bank performance during the period 2002-2011 with predictor variables such as board size, board composition, gender diversity CEO duality, and ROE and ROA for performance measurement. In Bangladesh, Mohammed and Fahmida (2017) investigated the effect of corporate governance on the performance of commercial banks with predictor variables such as board size, board composition, audit committee member, capital adequacy, and ROE, ROA, and EPS for performance measurement. Interestingly, all these studies report a mixed impact of corporate governance on the performance level of banks thereby creating a gap for more studies to be conducted.

In Nigeria, a lot of studies have been conducted in this context in the banking sector Using ROA and ratio of non-performing loan, Mohammed (2012) examined the impact of corporate governance on the performance of banks in Nigeria. Also, Ajala, Amuda, and Arulogun (2012) examined the effect of corporate governance on the performance of Nigerian banking sector with variables such as board size, board composition, corporate governance index as predictor variables, and ROA and ROE as performance measurement. Adegbami, Donald and Ismail (2013) investigated the impact of corporate governance on bank performance in Nigeria with PAT as the outcome variable.

In the study conducted by Gadi, Emesuanwu and Shammah (2015) on the impact of corporate governance (CG) on microfinance bank's financial performance in Nigeria, with board size and broad composition as predictor variables, and ROA and EPS for performance measurement. In the same vein, Adigwe, Nwanna, and John (2016) examined the effect of corporate governance mechanism on the financial performance of banks in Nigeria with independent variables of broad size, board composition, board audit committee, and ROA as performance measurement. Another study was conducted by Okoye, Evbuomwan, Achugamonu, and Aragham (2016) with specific variables such as capital adequacy, liquidity ratio, ration of non-performing loans, ROA and ROE. Using variables such as the board of directors, total employees and PAT for performance measurement, Agbaeze, and Ogosi (2018) examined the impact of corporate governance on the profitability of Nigerian banks.

Findings reported by these studies were mixed. While studies like Mohammed (2012), Adigwe, Nwanna and John (2016), Okoye, Evbuomwan, Achugamonu and Aragham (2016), Agbaeze and Ogosi (2018), reported a positive impact of corporate governance on the performance level of banks, studies like Ajala, Amuda and Arulogun (2012) and Adegbami, Donald and Ismail (2013) reported a negative impact thereby creating a gap for more studies to be conducted. Noticeably from all these studies, particularly those conducted in Nigeria, CEO duality seems not to be well appreciated by researchers and thereby constitute another gap this paper intends to fill.

Similarly, correlation and multiple regression were the methods of analysis used by these studies. This, therefore, constitutes another vacuum this present study intends to fill with the use of panel data regression analysis. To emphasize the need for corporate governance as a productive tool for improved performance of Deposit Money Banks in Nigeria, this study tries to examine the effect of corporate governance on the performance of Deposit Money Banks in Nigeria. Specifically, the study is designed to examine the effect of board audit committee, board composition, CEO duality, gender diversity, board size on the performance of Deposit Money Banks in Nigeria.

The timeliness of this study is rooted on the intermittent financial scandals that engulfed DMBs in Nigeria, 
and have shaken stakeholders' faith on the usefulness of the current practices of corporate governance in promoting transparency and accountability. This seems to have affected the relative performance of the banks leading to wastefulness and reduced profit level. This has also reduced the inflow of foreign direct investment in the banking institution.

\section{Literature Review}

\subsection{Corporate Governance and its Mechanisms}

The concept of Corporate Governance is not new and has received significant attention after the collapse of Enron Corporation, Tyco and World co. Corporate governance refer to the way a corporation is governed. According to Ochieng (2011), it is the collection of mechanisms, processes and relations by which organizations are controlled and operated. Supporting this, Anastasia and Olga (2012) viewed corporate governance as the mechanism of guidelines, activities and processes by which a company is directed and controlled. This indicates that corporate governance majorly encompasses the balancing of interests of company's stakeholders. It provides an outline for realizing a company's objectives and encompasses every sphere of management, from action plan to internal controls, performance evaluation and corporate disclosure.

Corporate governance is specifically concerned with the set of rules, controls, policies and resolutions put in place that dictates corporate behaviour (Mohammed \& Fahmida, 2017). In the same vein, Ayorinde, Toyin and Leye (2012) sees it as a framework of guidelines and practices that enables board of directors to ensure accountability, fairness and transparency in a corporate relationship with all its stakeholders. Corporate governance framework consists of explicit and implicit contracts between companies and their stakeholders for distribution of rights, procedures, responsibilities and rewards for merging the conflicting interest of stakeholders in harmony with their privileges, duties and roles and finally, measures for control, information and proper supervision flows to perform as a scheme of checks and balances (Michael, 2016).

Corporate governance mechanisms have no limitations, that is, the mechanisms are numerous. However, due to the coverage of this paper in terms of the organization and the gap to be filled, board composition, gender diversity, board size, the CEO duality and board audit committee are used for corporate governance mechanisms. The board is typically the governing body of the organization and its prime responsibility is to make sure that the organization completes the shareholders' goal. The board of directors have the power and authority to terminate, hire and remunerate top management (Hani, 2014). The board secures the corporation's invested capital and assets. In addition to outlining bank's objectives which include generating returns to shareholders, the board of directors and senior management as noted by Okoye, Evbuomwan, Achugamonu and Aragham (2016), influence how banks run their daily operations, achieve the commitment of accountability to shareholders and consider the interests of other recognized stakeholders (Harun, 2017).

Boards of directors are responsible for the governance of their companies. The shareholders' role is to select and assign directors and to placate themselves that a competent governance structure is in place and the board consists of executive and non-executive director. The responsibilities and obligations of the executive directors include outlining the company's tactical goals, offering the skill and expertise to put them into effective use, coordinating and administering the leadership of the business, and giving account to shareholders on their stewardships (Ajala, Amuda \& Arulogun, 2012). A non-executive director is one who is not employed by the organization and also has no relation with the organization other than being a director (Adigwe, Nwanna \& John, 2016). They are selected and employed on a part-time agreement and carry out diverse responsibilities including acting as the company's chairperson and presiding over different major committees such as nominations Committee, remuneration committee and audit Committee (Michael, 2016).

Chief Executive Officer (CEO) duality is the practical definition of one person functioning as both the chairperson of the board of directors and the CEO. According to Vintilla and Duca (2013) CEO duality refers to the situation where the CEO also holds the position of the chairman of the board. In the same vein, Robisson, Onyeanu and Obodoekwe (2013) opined that duality role in a company means a person who has a dual role as Chairman of the board (COB) and Chief Executive Officer (CEO) at the same time. The board of directors is set up to monitor managers such as the CEO on the behalf of the shareholders. They plan compensation agreements and contracts, employ and dismiss CEOs. A twofold CEO profits the firm if he/she works diligently with the board to generate worth.

Boardroom diversity has been gathering attention as the perception of corporate governance is gaining momentum. There are a lot of aspects of boardroom diversity, but gender diversity specifically is attracting the consideration of various corporations. Gender diversity refers to the presence of women on corporate boards of directors or women representation on boards (Anastasia \& Olga, 2012). The opinion that gender diversity can be beneficial to business is widely accepted, however, the rate at which women are being integrated into senior position is very low (Salma \& Cesario, 2016). The explanation for the positive effect of gender diversity among board members is that it increases creativity and innovation by adding complementary knowledge, skills and experience. Empirical evidence depicts the presence of women directors in board level positions as responsible for 
various organizational outcomes (Salma \& Cesario, 2016). The connection between gender diversity and organizational performance has remained inconclusive, hence it is still available to further empirical investigation. Empirical studies such as Julizaerma and Sori (2012) established that a positive and significant relationship exists between gender diversity and organizational performance.

In order to promote corporate governance on the part of the directors and reporting function of auditors, to enhance or improve the credibility of the financial statement and to protect shareholder interest in general, section 359(3) of Companies and Allied Matter Act (CAMA, 1990) provides that every public company should establish audit committee. The committee shall consist of six members which include three directors and three representatives of shareholders (Abiola \& Adesanwo, 2017). According to Ahmed (2014), audit committee functions as a subset of the board of directors from whom it obtains its powers and authorities to properly execute its corporate governance obligations which entails supervising and watching the organization's internal and external audit, disclosure, financial reporting, internal control, regulatory submission and risk management activities. The audit committee delivers essential evidences and recommendations to the board of directors, including ensuring that the organization submits to significant guidelines and ethical principles and standards, ensuring that the internal auditors are sovereign and competent, ensuring that the financial statements have been properly prepared and that the compensations paid to the organization's executives are according to fairness and professionalism.

\subsection{Firms' Performance}

Firm performance is the ability of a firm to generate revenue in such a way that it exceeds cost, in connection to the firm's capital base. Notably, a strong and profitable firm is better able to resist negative shocks and contribute more to the stability and development of the financial system. Ongore and Kusa (2013) defined profitability as a relationship that exist between the profits generated by a company and the investments that backed up the attainment of these profits. They also stated that profitability ratios calculate the competence with which a company converts business activity into profits. Profit margins evaluate the capability to convert revenue into profits. Return on assets evaluates the ability to use assets to create net income. Expanding this, literature affirmed that the absence of confidence in the operational activities of the banking sector is toxic to the performance level mostly measures in terms of Return on Assets (ROA), Return on Equity (ROE), Net Profit Margin (NPM) and Profit after Tax (PAT) (Adigwe, Nwanna \& John, 2016; Pitambar, 2017).

Basically, the profitability of firms in the Deposit Money Banks sector could be measured using; Return on Assets (ROA) which focus on the capacity to create income through the optimization of a firm's assets; Return on Equity (ROE) which evaluates how much profit is earned comparatively to shareholders' equity; Earning per Share (EPS) which depicts the quota of a company's taxes (net), earnings and preferred stock dividends, that is distributed to each share of common stock; and Profit After Tax (PAT) which represents the figure earned by a firm after all taxation related expenses have been subtracted (Gul, Faiza \& Khalid, 2011). Observably, while some DMBs are thriving in the industry, it seems others are financially distressed.

\subsection{Conceptual Framework}

The relationship between the predictor variables and the outcome is depicted in figure 1:

$$
\begin{aligned}
& \text { Board Audit Committee } \\
& \text { Board Composition } \\
& \text { CEO Duality } \\
& \text { Gender Diversity } \\
& \text { Board Size }
\end{aligned}
$$

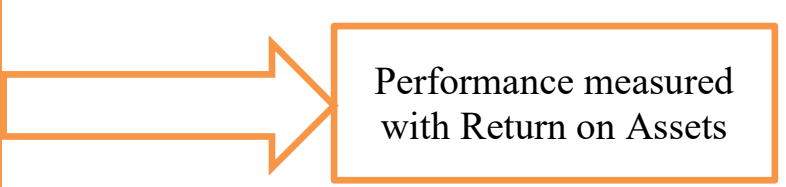

Figure 1: Conceptual Framework Source: Author's Design

This is an indication that the performance of Deposit Money Banks in Nigeria measured in term of Return on Assets (ROA) depends on the mechanisms of corporate governance which include board audit committee, board composition, CEO Duality, gender diversity and board size.

\subsection{Theoretical Framework}

This study is theoretically underpinned by shareholders' theory, propounded by Friedman in 1970. It deals with how corporate leaders should deal in their business environment and emphasize that priority should be placed on shareholders' interest. Friedman (197) wrote in New York Times that there is only one social responsibility of business which is the use of its resources to carry out activities specified to increase its profits, as long as it remains within the rules and regulations of the game. Implicitly, this opinion states that a business can engage in any open 
and free competition without trickery or scam, as long as that activity is not illegal. The idea of shareholders' theory is that managers ultimately have an obligation to maximize shareholders' interest in a way that is allowed by social values or law.

According to this theory, the objective of the firm is to maximize shareholder wealth, in other words, a firm's only purpose is to serve the needs and interests of the firms' owners. The criteria by which performance is judged in this theory is simply taken as the market value (i.e. shareholder value) of the firm. Basman (2017) opined that shareholder wealth maximization should be the overall goal of every corporate entity. Maximization of shareholder's wealth ensures that shareholders are adequately compensated for risk undertaken. Shareholder wealth includes dividends and importantly capital appreciation of the investors' investments.

The criticism to this theory is that it is rather misleading to argue that the shareholders are the sole residual claimant in the company especially under circumstances when the company is not bankrupt. It is not the shareholder's firm specific investments that made their position more vulnerable when compared to other stakeholder groups. As employees, suppliers and other constituencies have contributed to the firm's success and they suffer as well when the company performs poorly. The implication of this theory on this paper is that corporate governance should take the shareholder's interest into utmost consideration.

\subsection{Empirical Review}

Undoubtedly, a lot of studies have been conducted on how corporate governance could improve the performance of organizations in developed countries, developing countries and Nigeria. Some of these studies are reviewed. Mohammed (2012) examine the impact of corporate governance on performance of banks in Nigeria using multiple regression analysis. The paper backed up the hypothesis that corporate governance positively affects performance of banks. Ajala, Amuda and Arulogun (2012) evaluate the effect of corporate governance on Nigerian banking sector using Pearson correlation and regression analysis. The study revealed that a negative but significant relationship subsisted between board size and the financial performance of these banks, while a positive and significant relationship was also observed between directors' equity interest, level of corporate governance disclosure index and performance of the sampled banks. The study outlined that efforts to improve corporate governance should focus on the value of the stock ownership of board members and that steps should be taken for mandatory compliance with the code of corporate governance.

Adegbami, Donald and Ismail (2013) examine Corporate Governance and bank performance: A pooled study of selected banks in Nigeria. The study made use panel regression analysis. The findings revealed that corporate governance had been on the low side and had impacted negatively on bank performance. The study suggested that strategic training for board members and senior bank managers should, be embarked or improved upon, especially on courses that promote corporate governance and banking ethics. Adekunle and Aghedo (2014) investigated the impact of corporate governance on the financial performance of selected listed firm in Nigeria with Return on Assets (ROA) and Profit Margin (PM) as dependent variables and composition of board membership, board size, CEO status and ownership concentration as independent variables. The study made use of multiple regression analysis. The analysis showed that there was a positive and significant relationship between composition of board member and board size and firm performance. However, a negative relationship was established between ownership concentration and Return on Assets.

Gadi, Emesuanwu and Shammah (2015) examine the impact of corporate governance on financial performance of micro finance bank in North central Nigeria using Pearson correlation coefficient and ordinary least square (OLS). The Pearson correlation showed that a significant relationship existed between Earnings per share (EPS) and corporate governance (Board Composition and Composition of Board Committees), while the regression analysis showed that no significant relationship existed between corporate governance and bank's financial performance. However, there were areas of non-compliance which included the appointment of Executive Directors and Managing Directors and sometimes Chief Executive Officer as Board committee members. Finally, the study highlighted that board of directors of microfinance banks should adhere strictly to the provisions of the code of corporate governance on Board Composition (BC) and Composition of Board Committees (CBC).

Mugisha, Jaya, Joseph and Mbabazi (2015) examine the effect of corporate governance on the financial performance of banking industry in Rwanda: A case study of commercial bank in Rwanda using regression analysis. The study revealed that board independence, board composition and institution ownership do not have an effect on financial performance since the majority of respondent disagreed that there is no effect of corporate governance variables on the financial performance of commercial banks. Okoye, Evbuomwan, Achugamonu and Araghan (2016) examine the impact of corporate governance on the profitability of Nigerian banking sector using correlation analysis. Empirical evidence from the study unveiled significant impact of corporate governance on the profit performance of the Nigerian banking sector. It was recommended that the regulatory authorities (CBN, NDIC and SEC) should diligently exercise their oversight functions to ensure strict compliance, by the banking sector, to extant regulations on corporate governance so as to consolidate, or possibly, improve on the gains of the 
initiative.

Salma and Cesario (2016) examine corporate governance impact on bank performance evidence from Europe using multiple regression analysis. The results showed that the board size and the gender diversity had a positive and significant impact on bank performance. Large board of directors with more female members led to better bank performance, whereas, the board composition and the CEO duality had no significant effect in explaining the bank performance for the European countries. During the global financial crisis, findings uncovered that the board size and the board composition were negatively and significantly correlated to the bank performance. Smaller boards of directors with less number of independent (non-executive) directors have outperformed the ones with larger boards and more independent directors during the crisis. However, the gender diversity and the CEO duality had no significant impact on the European bank performance.

Mohammed and Fahmida (2017) examine the impact of corporate governance on performance of commercial banks in Bangladesh using regression and correlation analysis. The result showed that Board size, the number of independent directors and number of internal audit committee members were inversely related to bank performance. Regression results also uncovered that there was a linear relationship between capital adequacy ratio and return on asset, but a nonlinear relationship between CAR and two other performance measures; return on equity and earnings per share. Ulussever (2018) conducted a comparative analysis of corporate governance and bank performance: Islamic banks versus conventional banks using regression analysis and two -steps generalized methods of moments. The results showed that boards were strong and the CEO's were powerful in Islamic banks. While the return variables of Islamic banks were positively correlated with the financial disclosure index and board structure variables, they were negatively correlated with the risk closure index and CEO related variables. The corporate governance and financial disclosure indices lessened the profitability of Islamic banks as they were negatively significant with performance variables.

Agbaeze and Ogosi (2018) examined the effect of corporate governance and profitability in Nigerian banks using correlation and regression analysis. The correlation result revealed that there was a positive relationship between profitability of Nigerian banks and corporate governance measured by number of members in the board of Nigerian banks and also there was a positive relationship between profitability of Nigerian banks and the number of employees and, corporate governance measured by number of members on the board had a positive and significant impact on profitability of Nigerian banks. Again, the number of employees had positive and significant impact on profitability of Nigerian banks. The study therefore concluded that corporate governance had an impact on profitability of Nigerian banks.

Studies on corporate governance and firms' performance are numerous however, they seem inconclusive. While studies reported a positive impact of corporate governance on the performance level of banks, other reported a negative impact thereby creating a gap for more studies to be conducted. Noticeably from all these studies, particularly those conducted in Nigeria, CEO duality and gender diversity have not been well researched corporate governance metrics that could affect the performance firms. This paper intends to incorporated these corporate governance indicators in the study. Similarly, correlation and multiple regression were the methods of analysis used by these studies, except a study conducted by Adegbami, Donald and Ismail (2013) and those conducted in the developed countries. This, therefore, constitutes another vacuum this paper intends to fill with the use of panel regression analysis.

\section{Methodology}

The ex-post facto research design was employed and out of the 17 listed Deposit Money Banks in Nigeria, simple random technique was used to select $10 \mathrm{DMBs}$ as the paper participants. The data used for this study were secondary data collected from the audited financial statements of 10 Deposit Money Banks listed on the Nigerian Stock Exchange (NSE) for ten years, spanning from 2008 and 2017. The banks are Access Bank Plc, Ecobank Nigeria Plc, Fidelity Bank Plc, Guaranty Trust Bank Plc, Polaris Bank Ltd, First Bank Plc, Union Bank Nigeria Plc, United Bank for Africa Plc, Wema Bank Plc. and Zenith Bank Plc. Data were collected on a single performance variable of Return on Assets (ROA) and components of corporate governance such as board audit committee, board composition, CEO duality, gender diversity and board size. The research employed only quantitative method of data analysis. Multiple regression was carried out so examine the effect of corporate mechanisms on the performance of Deposit Money Banks in Nigeria proxies by Return on Assets (ROA).

The study adapted the model used by Adigwe, Nwanna, and John (2016) to examine the effect of corporate governance on financial performance of Deposit Money Banks in Nigeria where Return on Assets (ROA) is made a full function of board audit committee, board composition, and directors; equity interest. Mathematically, the model is specified below:

$R O A=f(B A C B O C D E I)$

Where:

ROA: Return on Assets

BAC: Board Audit Committee 
BOC: Board Composition

DEI: Directors' Equity Interest

$f=$ Functional Relation

The model was modified specifying ROA as a function of board size, board composition, board audit committee, gender diversity, and CEO duality. The modification was necessary in that the importance of corporate governance to the performance level of firms is better captured comprehensively when indicators of corporate governance such CEO duality, gender diversity and board size were used alongside board composition and board audit committee. Also, the model of this study made use of the total number of employees as the control variable because employees are livewires of any organization and that the structure of an organization determines the total number of staff employed. Mathematically, the model is given below:

$R O A=f(B A C B O C$ CED GED BOS $)$

Therefore, equation specification in its logarithm form is then:

$R O A_{i t}=\beta_{0}+\beta_{1} B A C_{i t}+\beta_{2} B O C_{i t}+\beta_{3} C E D_{i t}+\beta_{4} G E D_{i t}+\beta_{5} B O S_{i t}+U_{i t}$

Where:

$\mathrm{BAC}=$ Board Audit Committee

$\mathrm{BOC}=$ Board Composition

CED: CEO Duality

GED: Gender Diversity

BOS: Board Size

Where:

$\beta_{0}=$ Intercept

it $=$ represents the combination of time and individuality

$\mathrm{U}_{\mathrm{it}}=$ error term

This study used descriptive statistics of mean, standard deviation, minimum and maximum values to describe the variables used in the study. This was followed by correlation matrix, pooled OLS estimation, fixed effect estimation and random effect estimation and Hausman test and other post estimation test. The fixed effect is given below:

$Y_{i t}=a_{0}+\beta_{1} X_{i t}+\delta i+\mu_{i t}$ 3.4

$\delta i$ is a time-varying intercept that captures all the variables that affect $Y_{\text {it }}$ that vary over time but are constant crosssectionally. In substituting the variables under consideration into the fixed effect model, it will appear thus:

$R O A_{i t}=a_{0}+\beta_{1} B O S_{i t}+\beta_{2} B O C_{i t}+\beta_{3} B A C_{i t}+\beta_{4} C E D_{i t}++\beta_{5} G E D_{i t}+\beta_{6} T O E_{i t}+ð i+\mu_{i t} \ldots \ldots .3 .5$

The random effect model follows the forms presented below:

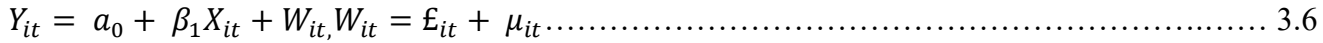

Where $\epsilon_{i t}$ measures the random deviation from the global intercept a, subscript "it" represents the combination of time and individuality. $U_{i t}$ means error term. In substituting the variables under consideration into the fixed effect model, it appears thus:

$R O A_{i t}=a_{0}+\beta_{1} B O S_{i t}+\beta_{2} B O C_{i t}+\beta_{3} B A C_{i t}+\beta_{4} C E D_{i t}++\beta_{5} G E D_{i t}+\beta_{6} T O E_{i t}+\left(\delta i+\mu_{i t}\right) \ldots 3.7$

\subsection{Results}

4.1 Descriptive Analysis

Table 1: Descriptive Statistics of Variables

\begin{tabular}{|l|l|l|l|l|l|}
\hline Variable & Observation & Mean & Std. Dev. & Min & Max \\
\hline ROA & 100 & 8.17 & 10.10 & -14.28 & 37.55 \\
\hline BOS & 100 & 9.31 & 2.75 & 4 & 17 \\
\hline BAC & 100 & 0.6185 & 0.143 & 0 & 0.91 \\
\hline CED & 100 & 5.42 & 0.965 & 4 & 7 \\
\hline GED & 100 & 0.66 & 0.476 & 0 & 1 \\
\hline TOE & 100 & 0.102 & 0.096 & 0.00 & 1 \\
\hline
\end{tabular}

Note: ROA is Return on Assets, BOS is Board Size, BOC is Board Composition, BAC is Board Audit Committee, CED is CEO Duality, GED is Gender Diversity and TOE is Total Number of Employee

Source: Data Analysis (2020)

Table 1 revealed the summary of all the variables under consideration. It revealed that the mean value of ROA to be 8.17, indicating that each Deposit Money Bank in the industry could make an average of \#8.17 on the net investment with a higher degree of risk as the returns varied at both sides of the scale by a large margin of $10.1 \%$. In the same vein, ROA ranged from a negative return of \#14.28 to a maximum value of \#37. The inference is that for every one naira invested, the industry could make a loss of \#14.28 and make a maximum gain of \#37.55. For the board size, 9 people constituted the average number of members of the board across the firms in the 
industry, ranged from a minimum of 4 and a maximum of 17 with a lower degree of risk of 2.75 . BOC has a mean value of 0.6185 flagged with a minimum and maximum value of 0 and 0.91 . Similarly, BAC has a mean value of 5.42 brace with a minimum and maximum values of 4 and 7 respectively. Regarding the CEO duality, $66 \%$ of the CEO is also the chairman of the board but; the remaining $34 \%$ has a separation between the function of the chairman and CEO. GED has an average value of 0.102 with the values of minimum and maximum given to 0 and 1 respectively. This is an indication that the membership of the board of some of Deposit Money banks is not restricted to one gender.

4.2 Correlation Analysis

Table 2: Correlation Statistics

\begin{tabular}{|l|l|l|l|l|l|l|l|}
\hline & ROA & BOS & BOC & BAC & CED & GED & TOE \\
\hline ROA & 1 & & & & & & \\
\hline BOS & -0.2878 & 1 & & & & & \\
\hline BOC & -0.3987 & 0.0516 & 1 & & & & \\
\hline BAC & 0.1299 & 0.5815 & 0.1745 & 1 & & & \\
\hline CED & 0.0867 & 0.0807 & 0.1377 & 0.0597 & 1 & & \\
\hline GED & 0.0224 & 0.1576 & 0.1771 & 0.1963 & 0.0260 & 1 & \\
\hline TOE & 0.0664 & 0.0929 & 0.0727 & 0.1137 & 0.1069 & 0.0130 & 1 \\
\hline
\end{tabular}

Source: Data Analysis (2020)

Table 2 shows that there is a negative relationship between return on assets and board size to the tune of 0.2878 , reflecting that both variables, return on assets and board size, move towards different directions. The same explanation holds for the relationship between return on assets and board composition with a correlation coefficient of -0.3987 . the result equally shows that return on assets equally maintained a positive relationship with board audit committee, CEO duality, gender diversity and the total number of employees with their respective correlation coefficient of $0.1299,0.0867,0.0224$ and 0.0664 . The relationship between all the predictor variables is positive all through, reflecting that they all maintained a positive relationship.

\subsection{Panel Regression Analysis}

This section presents the analysis of the effect of corporate governance in terms of board size, board composition, board audit committee, CEO duality, gender diversity and total number of the employee on the performance of Deposit Money Banks in terms of return on Assets. In this section, results of analyses done using Pooled OLS estimator, fixed effect estimator and random effect estimation are presented after which evaluation for consistency and efficiency was done using post estimation test including restricted F-test and Hausman test. Emphasis is being placed on the most consistent and efficient estimator for discussion and inference.

\subsubsection{Pooled OLS Analysis}

Table 3 Pooled OLS Estimation Result

\begin{tabular}{|l|l|l|l|l|}
\hline Variable & Coefficient & Std Error & T-Test & Probability \\
\hline C & 16.9755 & 5.2977 & 3.83 & 0.001 \\
\hline BOS & -0.2287 & 0.0694 & 2.27 & 0.035 \\
\hline BOC & -8.6512 & 1.3713 & 2.65 & 0.022 \\
\hline BAC & 1.4063 & 2.1916 & 1.03 & 0.308 \\
\hline CED & 1.8938 & 11.141 & 0.86 & 0.390 \\
\hline GED & 3.4333 & 0.6506 & 0.31 & 0.759 \\
\hline LogTOE & 0.5974 & 0.1650 & 3.69 & 0.001 \\
\hline
\end{tabular}

$R$-square $=0.445$, Adjusted R-square $=0.4172, F$-statistics $=8.72$, Prob $(F$-stat $)=0.0034$

Source: Data Analysis (2020)

Table 3 reveals that both board size and board composition exert a negative and significant effect on return on assets to the tune of $-0.2287(\mathrm{p}=0.035<0.05)$ for board size and $-0.86512(\mathrm{p}=0.022)$ for board composition. Consequently, board audit committee, CEO duality and gender diversity exert a positive but insignificant effect on return on assets to the tune of $1.4063(\mathrm{p}=0.308>0.05)$ for Board audit committee, $1.8938(\mathrm{p}=0.390>0.05)$ for CEO duality and $3.4333(\mathrm{p}=0.759>0.05)$ for gender diversity. Total number of employees exerts a positive and significant effect on the return on assets to the tune of $0.5974(\mathrm{p}=0.001<0.05)$. Reported Adjusted R-square of 0.4445 revealed that $45 \%$ of the systematic variation in return on assets can jointly be explained by all the predictor variables while the remaining $55 \%$ could be accounted for by other variables not covered by this paper. The Fstatistics of 8.72 along the probability value of 0.0034 revealed that the model is fit. 


\subsubsection{Fixed Effect Estimation}

Table 4.: Fixed Effects Estimates (Cross-sectional and Period specific)

\begin{tabular}{|l|l|l|l|l|l|}
\hline CROSS-SECTIONAL SPECIFIC EFFECT & TIME SPECIFIC EFFECT & Prob \\
\hline Variables & Coefficients & Prob & Variables & Coefficients & 0.001 \\
\hline C & 9.9042 & 0.001 & C & 2.85702 & -2.0820 \\
\hline BOS & -0.9497 & 0.029 & BOS & -3.2834 & 0.001 \\
\hline BOC & -4.0737 & 0.016 & BOC & 1.7406 & 0.673 \\
\hline BAC & 1.7009 & 0.685 & BOA & 0.5730 & 0.799 \\
\hline CED & 1.4503 & 0.545 & CED & 17.695 & 0.241 \\
\hline GDE & 11.875 & 0.453 & GDE & 0.5549 & 0.196 \\
\hline LOGTOE & 0.45091 & 0.807 & LOGTOE & & \\
\hline Effects & & & Effects & & 0.372 \\
\hline ECO BANK & 4.8033 & 0.204 & 2009 & -2.4303 & 0.178 \\
\hline FIDELITY BANK & -1.7580 & 0.379 & 2010 & 3.2310 & 0.661 \\
\hline GTB & 2.3720 & 0.020 & 2011 & -1.2375 & 0.669 \\
\hline STERLING BANK & 0.8315 & 0.967 & 2012 & -1.0401 & 0.244 \\
\hline FIRST BANK & -1.6194 & 0.001 & 2013 & -2.9442 & 0.232 \\
\hline UNION BANK & 0.8994 & 0.720 & 2014 & -2.5137 & 0.532 \\
\hline UBA & -6.5760 & 0.054 & 2015 & -1.3176 & 0.583 \\
\hline WEMA BANK & -0.9323 & 0.005 & 2016 & -1.6342 & 0.383 \\
\hline ZENITH BANK & 0.1189 & 0.967 & 2017 & -2.0426 & \\
\hline $\begin{array}{l}\text { Adjusted R-square }=0.7663 \\
\text { F-statistics=54.46 } \\
\text { Prob(F-stat)=0.0000 }\end{array}$ & & Adjusted R-square $=0.5413$ & \\
\hline
\end{tabular}

Source: Data Analysis (2020)

Fixed effect cross-sectional specific estimation result presented in Table 4 reveals that board size and board composition have a negative but significant effect on return on assets with the coefficient and p-value of -0.9497 and 0.029 for board size, and -4.0737 and 0.016 for board composition. Also, the remaining variables which are board audit committee, CEO duality, gender diversity and Log of total employees all have a positive but insignificant effect on return on assets. This is further displayed with their coefficient and prob value of $1.7009(0.685), 1.4503(0.545), 11.875(0.453)$ and $0.45091(0.807)$ respectively. Overall, the results shows that the adjusted R-square value which stood at 0.7660 implies that about $76.6 \%$ of the systematic variation in return of assets of Deposit Money Banks in Ekiti State was jointly caused by all the predictor variables. Also, the f-statistics and its prob. Value which were represented with 54.46 and 0000 shows that the result was fit and statistically significant.

Also, result of fixed effect period-specific estimation presented in table 4.4 shows that board size and board composition have negative and significant effect on return on asset on time specific effect while board audit committee, CEO duality, gender diversity and Log of total employees have positive and insignificant effect on return on asset on time specific effect for the period covered by this study. This is indicated by the values of the coefficient and p-value given to be -2.0820 and $0.001,-3.2834$ and $0.001,1.7406$ and $0.673,0.5730$ and 0.799 , 17.695 and 0.241 and 0.5549 and 0.196 respectively. Also, the adjusted R-squared shows that about $54 \%$ variations in return on asset on time specific effect can be attributed to board size, board composition, board audit committee, CEO duality, gender diversity and $\log$ of total employees while the remaining $46 \%$ variations in return on asset on time specific effect are caused by other variables not included in this model. This shows a strong explanatory power of the model. This is further emphasized by the probability of the f-statistic given to be 0.000114 which shows that the regression result is statistically significant because this is less than $5 \%$, the level of significance adopted for this study.

Deviation from the intercept term (9.9042) corresponding to the reference firms (Access Bank) stood at 4.8033, - $1.7580,2.3720,0.8315,-1.6194,0.8994$. -6.5760, -0.9323 and 0.1189 for ECO BANK, FIDELITY BANK, GTB, STERLING BANK, FIRST BANK, UNION BANK, UBA, WEMA BANK and ZENITH BANK. In the same vein, deviation from the intercept term (2.85702) of the reference period (2008) stood at -2.4303 , $3.2310,-1.2375,-1.0401,-2.9442,-2.5137,-1.3176,-1.6342$ and -2.0426 for $2009,2010,2011,2012,2013,2014$, 2015,2016 and 2017 respectively. 


\subsubsection{Random Effect Estimation}

Table 5 Random Effect Estimation

\begin{tabular}{|l|l|l|l|l|}
\hline Variable & Coefficient & Std. Error & Z-Test & Probability \\
\hline C & 10.2871 & 2.9077 & 6.79 & 0.000 \\
\hline BOS & -0.8462 & 0.3598 & 2.37 & 0.009 \\
\hline BOC & -2.3177 & 0.2111 & 4.28 & 0.001 \\
\hline BAC & 1.3748 & 2.1134 & 0.65 & 0.515 \\
\hline CED & 2.4951 & 2.0646 & 1.21 & 0.227 \\
\hline GED & 5.1647 & 12.720 & 0.41 & 0.685 \\
\hline LogTOE & 4.5103 & 1.8671 & 2.59 & 0.003 \\
\hline
\end{tabular}

Source: Data Analysis (2020). R-square $=0.4445$, Wald chi2(5) $=13.12$, Prob $>\operatorname{chi} 2=0.0001$

Source: Data Analysis, (2020)

Table 5 reveals that both board size and board composition exert a negative and significant effect on return on assets to the tune of $-0.8462(\mathrm{p}=0.009<0.05)$ for board size and $-2.3177(\mathrm{p}=0.001<0.05)$ for board composition. Consequently, board audit committee, CEO duality and gender diversity exert a positive but insignificant effect on return on assets to the tune of $1.3748(\mathrm{p}=0.515>0.05)$ for Board audit committee, $2.4951(\mathrm{p}=0.227>0.05)$ for CEO duality and $5.1647(\mathrm{p}=0.685>0.05)$ for gender diversity. The total number of employees exerts a positive and significant effect on return on assets to the tune of $4.5103(\mathrm{p}=0.003<0.05)$. Reported Adjusted R-square of 0.4445 revealed that $44 \%$ of the systematic variation in return on assets can jointly be explained by all the predictor variables while the remaining $56 \%$ could be accounted for by other variables not covered by this study. The Wald test of 13.12 along the probability value of 0.0001 revealed that the model is fit.

\section{4: Post estimation Test}

Table 6: Hausman Test

\begin{tabular}{|l|l|c|}
\hline Null hypothesis & Chi-square stat & Probability \\
\hline The difference in coefficient not systematic & 5.10 & 0.5309 \\
\hline
\end{tabular}

Source: Data Analysis (2020)

Table 6 reported chi-square statistic of 5.10 and probability value of 0.5309 . The result revealed that there is no enough evidence to reject that differences in coefficients of fixed effect estimation and random effect estimation are not significant. Therefore, the most consistent and efficient estimation is given by the random effect estimation as presented in Table 5. It thus became evident that the estimation that best explained the effect of corporate governance on the performance of Deposit Money Banks in Nigeria is the random effect estimation presented in Table 5, which reveals that both board size and board composition exerts a negative and significant effect on return on assets to the tune of $-0.8462(p=0.009<0.05)$ for board size and $-2.3177(p=0.001<0.05)$ for board composition. Consequently, board audit committee, CEO duality and gender diversity exert a positive but insignificant effect on return on assets to the tune of $1.3748(\mathrm{p}=0.515>0.05)$ for Board audit committee, $2.4951(\mathrm{p}=0.227>0.05)$ for CEO duality and $5.1647(\mathrm{p}=0.685>0.05)$ for gender diversity. Total number of employees exerts a positive and significant effect on return on assets to the tune of $4.5103(\mathrm{p}=0.003<0.05)$. Reported Adjusted R-square of 0.4445 revealed that $44 \%$ of the systematic variation in return on assets can jointly be explained by all the predictor variables while the remaining $56 \%$ could be accounted for by other variables not covered by this study. The Wald chi2 test of 13.12 along the probability value of 0.0001 revealed that the model is fit.

\section{5: Other Post Estimation Test}

Table 7: Other Post Estimation Test

\begin{tabular}{|l|l|l|}
\hline Wald test \\
\hline Null hypothesis & Statistics & Probability \\
\hline Panel homoscedasticity & 3.007 & 0.1182 \\
\hline Pesaran test & Probability \\
\hline Null hypothesis & Statistics & 0.5311 \\
\hline No cross-sectional dependence & 2.7813 & \\
\hline Wooldridge test & Statistics & Probability \\
\hline Null hypothesis & 0.9969 & 0.6776 \\
\hline NoAR(1)panel autocorrelation & & \\
\hline
\end{tabular}

Source: Data Analysis (2020)

Result presented in table 7 showed that there is no evidence to panel homoscedasticity, no cross-sectional dependence and no AR (1) panel autocorrelation, given the reported probability statistics of $0.1182>0.05$ for Wald test, $0.5311>0.05$ for Pesaran test, and $0.6776>0.05$ for Wooldridge test. Hence it can be established in the study 
that assumptions of the equal variance of residual terms, cross-sectional independence, and absence of serial autocorrelation for the estimated panel-based model are valid.

\subsection{Discussion of Findings}

This paper examines corporate governance and performance of Deposit Money Banks in Nigeria. From the result of the evaluation test which compared fixed effect and random effect, it was established that the most consistent and efficient estimator for the investigation conducted in this study is the random effect estimation presented in Table 5. It was discovered that board size exerts a negative and significant effect on the performance of Deposit Money Banks in Nigeria $-0.8462(\mathrm{p}=0.009<0.05)$. This implies that a $1 \%$ increase in the board size would breed 0.8 decreases in the performance of banks in Nigeria. This implies that the roles of the members of the board in improving the monitoring functions, improve governance and increase returns have not been productive in terms of return on assets. The corollary of this discovery is that the performance of Deposit Money Banks in Nigeria tends to decrease if there is an increase in the board size. This outcome gave credence to the findings of Ajala, Amuda, and Arulogun (2012) and Uwuigbe (2011), that there was a negative and significant relationship between board size and the performance of banks in Nigeria.

Another discovery made was that board composition exerts a negative and significant effect on return on assets of Deposit Money Banks in Nigeria to the tune of $-2.3177(\mathrm{p}=0.001<0.05)$. This indicates that a $1 \%$ increase in board composition would breed a decrease in the performance of Deposit Money Banks in terms of return on assets. This explains that the objective view of the non-executive directors regarding the operational activities of the banks have not been productive. The inference of this discovery is that the board composition should be solely relied upon as a means to improve the performance level. This finding is tandem with the findings of Ahmed (2015) and Adigwe, Nwanna and John (2016), that board independence has negative and significant effects on ROA.

Another discovery is that board audit committee has a positive but insignificant effect on return on assets to the tune of $1.3748(\mathrm{p}=0.515>0.05)$, indicating that a $1 \%$ increase in the members of the audit committee in the board of directors would engender an increase in the performance level by $1.3 \%$. This is due to the fact that the audit committee provides the board of directors with necessary advice and recommendations. It is not significant probably because of the infringement on the independence of the committee, affecting the efficiency. This finding is at variance to the outcome of the study carried out by Adigwe, Nwanna and John (2016) that board audit committee has a positive and significant effect on the organizational performance. In the same vein, this outcome is in agreement with the discovery of Mohammed and Fahmida (2017) that board audit committee has an inverse relationship with organizational performance.

It was equally discovered that CEO duality has a positive but insignificant effect on the performance of on return on assets of Deposit Money Banks in Nigeria to the tune 2.4951 ( $\mathrm{p}=0.227>0.05$ ). This reflects that a $1 \%$ increase in the responsibility of the CEO would breed an increase in the performance of the banks but not in a significant way. The fact that the CEO is also the board chair of the directors has no significant impact on the bank performance because the additional responsibilities accorded to the CEO do not significantly add capacity to the CEO to influence the performance. This finding corroborates the outcome of Salma and Cesario (2016) that CEO duality has no significant effect in explaining the bank performance. However, this finding gives credence to the conclusion of Robisson, Onyeanu and Obodoekwe (2013), that efficiency of an organization is dependent on CEO duality.

The last discovery is that gender diversity exerts a positive but insignificant effect on the performance of Deposit Money Banks in Nigeria to the tune of $5.1647(\mathrm{p}=0.685>0.05)$. This explains that a $1 \%$ increase in the number of women on the board of directors would engender increase in the performance of banks insignificantly by $5.2 \%$. The positive effect is due to the general knowledge that the presence of the female on the board of directors has a crucial role in increasing the board's independence since women tend to ask different questions than male directors. Moreover, female directors are considered as a hardworking person and have better communication skills which enable them to add value in the firm by improving the decision-making ability and the problem solving of the board. However, the insignificant might be hinged on the premise that women are not always listened to in a congregation mostly dominated by men. This finding is in tandem with the submission of Salma and Cesario (2016) that gender diversity and CEO duality have no significant impact on bank performance. However, Julizaerma and Sori, (2012) established that a positive and significant relationship exist between gender diversity and organizational performance.

\subsection{Conclusion and Recommendations}

Based on the analysis carried out, it is hereby established that corporate governance exerts a significant effect on the performance of Deposit Money Banks in Nigeria. Specifically, it was concluded that both board size and board composition have no potency to stimulate an increase in the performance of banks in Nigeria in terms of return on assets. It was equally concluded that board audit committee, CEO duality and gender diversity can stimulate an 
increase in the performance of Deposit Moneys Banks in Nigeria but not in a significant way. Thus, the monitoring function of the members of the board of Deposit Money Banks should be directed at pressing needs such as the policies regarding the operational activities. This might breed discipline and increase the overall organization performance, CEO duality should be discouraged since additional responsibility accorded to the CEO cannot significantly increases the profit level and that the contribution of women in the board of directors should not only be heard, but it must also be used as and when necessary. In the same vein, similar study could extend to other sector of the economy like manufacturing firms.

\section{REFERENCES}

Chan, K.; Hameed, A. \& Kang, W. (2013); Stock price synchronicity and liquidityl, Journal of Financial Markets. Vol. 8 No. 5, pp. 47-67.

Crawford, S., Roulstone, D. T., \& So, E. C. (2012). Analyst initiations of coverage and stock return synchronicity. Accounting Review. Forthcoming. Available at SSRN.

Dasgupta, S., Gan, J., \& Gao, N. (2010). Transparency, price informativeness, and stock return synchronicity: Theory and evidence. Journal of Financial Quantitative Analysis, 45(5): 1189-1220.

Durnev, A., Morck, B., Yeunge, P. Z. (2003). Does Greater Firm-Specific Return Variation Mean More or Less Informed Stock Pricing?. Journal of Accounting Research, 41(5): 797-836.

Fang, Y. (2019). Analyst coverage and earnings management. Journal of Financial Economics, Vol. 188 No. 2 , pp. 245-271.

Feng, X.N. and Li, X.Y. (2011). Can China analysts reflect firm specific information: evidence from stock price synchronicity and analyst following?. Economic Science, No. 4, pp. 99-106.

Grewal, J., C. Hauptmann, and G. Serafeim. (2017). Stock price synchronicity and material sustainability information. Available At URL: Http://(www.ssrn.com).

Hasan, I., Song, L., \& Wachtel, P. (2014). Institutional development and stock price synchronicity: Evidence from China. Journal of Comparative Economics, 42(1), 92-108.

Kan, SH., \& Gong, S. (2017). Does High Stock Return Synchronicity Indicate High or Low Price Informativeness? Evidence from a Regulatory Experiment. International Review of Finance, DOI: 10.1111/irfi.12157, 1-24.

Mola, S. and Guidolin, M. (2009). A ffiliated mutual funds and analyst optimism. Journal of Financial Economics, Vol. 93 No. 1, pp. 108-137.

Nguyen Ngoc Thanh, V. (2013). Determinants of Stock Price Synchronicity evidence from HoChiMinh city stock exchange. Doctoral dissertation. Vietnam, International University HCMC).

Pan, Y., Dai, Y.Y. and Liu, S.C. (2011).Do underwriters provide price support by analyst coverage in China?. Journal of Economic Research, No. 3, pp. 131-144.

Piotroski, J.D., Roulstone, B.T. (2004). The influence of analysts, institutional investors, and insiders on the incorporation of market, industry, and firm-specific information into stock prices. Account. Rev: 1119-1151.

Rasheed, M. S., H. Bint Saeed, T. Yousaf, and F. Javed. (2018). Stock Price Synchronicity and Voluntary Disclosure in Perspective of Pakistan. European Online Journal of Natural and Social Sciences, 7(2): 265.

Scott, W. R. (2012). Financial accounting theory. Canada: Pearson Education.

Song, X., \& Zheng, W. (2014). Ownership structure, stock volatility and analyst independence. China Finance Review International, Vol. 4 Iss 2 pp. $187-208$.

Zhu, H.J., He, X.J. and Tao, L. (2007). Can China analysts increase the efficiency of capital market? Empirical research based on stock price synchronicity and price information content", Journal of Financial Research, No. 2, pp. 110-121. 